\title{
Aprendendo a escrever
}

\section{Caro Editor}

Em 12 de fevereiro de 1809 nascia em Shrewsbury, Inglaterra, o segundo filho do Dr. Robert, um respeitado médico local ${ }^{(1)}$. Embora fosse desejo de seu pai que o menino continuasse a tradição da família (seu avô também era médico), o jovem não suportou as aulas práticas de cirurgia em Edimburgo, sem anestesia na época, com pacientes aos berros e amarrados ao leito. Graças ao seu insucesso como futuro médico, a ciência ganhou um dos mais notáveis e revolucionários cientistas de todos os tempos: Charles Darwin, o mais famoso naturalista da história.

Escrevo este texto, não para comentar sua fracassada carreira de médico, mas para defender um ponto de vista acadêmico e editorial, com base em dois episódios da vida deste ilustre pensador.

No primeiro episódio, Darwin, após sua espetacular volta ao mundo a bordo do Beagle, estava com uma idéia recorrente que não lhe saía da cabeça: como explicar as origens das espécies. Em 1838, lendo o Ensaio sobre a população, de Thomas Malthus, lhe veio à mente uma possível explicação: na disputa pelos limitados recursos ambientais (alimentos, etc.), haveria uma competição natural entre os indivíduos (e entre espécies), sobrevivendo o melhor adaptado às condições ambientais vigentes. Nascia, assim o conceito da seleção natural para explicar a origem e a evolução das espécies, mais tarde publicado (1859) na célebre obra chamada The origins of species by means of natural selection. Portanto, embora posteriormente as idéias de Malthus fossem equivocadamente usadas em favor de hediondas políticas para justificar a eugenia em diversas partes do mundo, devemos reconhecer sua contribuição para o progresso da ciência, na obra de Darwin.

No segundo episódio, após a publicação de seu polêmico livro, Darwin, criticado por uns e idolatrado por outros, não conseguia explicar como ocorriam as variações nas características das espécies ao longo do tempo, uma vez que os conceitos modernos de genética (mutações, dominância entre genes, etc.) ainda não haviam sido descobertos. Infelizmente, Darwin morreu em 1882 sem entender como ocorriam os processos de hereditariedade, o que the teria ajudado a completar sua obra. Ironicamente, a chave para entender a hereditariedade foi descoberta enquanto Darwin ainda estava vivo, mas tais conceitos nunca chegaram ao seu conhecimento. Estes conceitos foram descobertos por um desconhecido monge austríaco chamado Gregor Mendel, o qual publicou um artigo de seus experimentos com ervilhas em 1866, em uma pequena revista científica de circulação local. Como
Mendel não era conhecido como pesquisador e a revista não tinha grande abrangência, seus conceitos permaneceram no esquecimento por muitos anos, até que, finalmente, foram descobertos e valorizados por outros cientistas, já no século XX.

Do primeiro episódio aqui relatado, verificamos que a evolução da ciência depende da soma de esforços individuais e percebemos o papel fundamental da consulta de diferentes fontes no processo de elaboração de uma obra científica. Neste sentido, a revisão da literatura consolida-se como parte crucial no processo de planejamento de projetos de pesquisa, bem como nas etapas de redação de artigos científicos.

Já no segundo episódio, percebemos que não basta realizar um magnífico e revolucionário conjunto de experimentos. É preciso saber divulgar da melhor maneira possível os resultados encontrados. No cenário atual, isto se traduz naquilo que o meio científico costuma reconhecer como o índice de impacto dos periódicos. Quanto maior for este índice, maior será a probabilidade de que o artigo venha a ser lido e que venha a influenciar outros autores. O progresso da ciência depende, portanto, do papel ativo do pesquisador em tentar publicar em periódicos que ofereçam maior visibilidade aos seus experimentos.

No presente ano de 2009, comemora-se o bicentenário do nascimento deste ilustre cientista chamado Charles Darwin e sua história de vida nos ensina que cabe a nós, pesquisadores, buscar sempre a melhor revisão possível da literatura em nossos artigos e a coragem de tentar publicá-los nas melhores revistas científicas.

Por último, parabenizo os esforços do Corpo Editorial dos Arquivos Brasileiros de Oftalmologia em sua batalha para fazer deste periódico uma publicação cada vez mais lida e respeitada no Brasil e no mundo.

Prof. Dr. Luciano P. Bellini

Professor de Oftalmologia - Faculdade de Medicina/UNISC

\section{REFERÊNCIAS}

1. Stefoff R. Charles Darwin: a revolução da evolução. São Paulo. Companhia das Letras, 2007.

Endereço para correspondência: Luciano P. Bellini. Av. Bastian, 230/302 - Porto Alegre (RS) CEP 90130-020

E-mail: lucianopbellini@yahoo.com.br
Professor Harley Edison Amaral Bicas

Editor Chefe - Arquivos Brasileiros de Oftalmologia

\section{Senhor Professor,}

Li com atenção e interesse o artigo "New comparative ultrasound biomicroscopic findings between fellow eyes of acute angle closure and glaucomatous eyes with narrow angle", que foi publicado nos Arquivos Brasileiros de Oftalmologia 2008;71(6): 
793-8 e apresenta achados comparativos de biomicroscopia ultrasônica (UBM) entre olhos contralaterias com fechamento angular agudo e olhos glaucomatosos com ângulo estreito.

Meu interesse advém do fato de que este assunto sempre foi para mim objeto de preocupação e interesse, por suas particularidades e desafios, pela possibilidade de se evitar em alguns pacientes, uma crise aguda de glaucoma e suas consequências.

Tanto que há 10 anos, em 1999, publiquei o artigo "Biomicroscopia ultra-sônica do segmento anterior de olhos com seio camerular passível de oclusão", com várias citações bibliográficas. Tal artigo foi publicado na revista Arquivos Bra- sileiros de Oftalmologia 1999;62(3):298-305 (disponível “on line"), e foi tema da minha Tese de Mestrado defendida na Universidade Federal de São Paulo (UNIFESP) em 1998, orientada pelo Prof. Dr. Paulo Augusto de Arruda Mello.

Tanto quanto eu saiba, até aquela data, era o único trabalho brasileiro sobre biomicroscopia ultra-sônica em pacientes com ângulo estreito.

Tendo em vista que o meu trabalho não figura na sua bibliografia, envio uma separata.

Respeitosos cumprimentos,

Ana Cláudia Alves Pereira

Ref.: Necessitamos su colaboración desde Cuba

\section{Señor Editor,}

Mis saludos

Le escribe Oreibis Lopez Informático de un Centro de Información Bibliotecaria en Cuba que brinda servicio a profesionales de la salud del Hospital Municipal de Minas en la Provincia de Camaguey. Me dirijo a usted pues se del prestigio y la profesionalidad de los artículos publicados en su revista y quisiera que los usuarios de nuestra institución pudieran acceder de forma impresa a estas publicaciones, por lo que le agradecería infinitamente que dentro de sus posibilidades nos enviara una donación de unos de sus ejemplares. Esto seria de mucha utilidad para el conocimiento de su obra por parte de nuestros médicos y personal capacitado, los que necesitan de estos artículos para desarrollar sus conocimientos.
Esperamos su respuesta y contamos con su apoyo para incrementar el nivel profesional de nuestros usuarios.

Muchas Gracias por la atención prestada.

Tec Informática: Oreibis López López Centro de Información Hospital Minas

La dirección donde puede enviar su revista si esta a su alcance seria:

Calle C \#4 \% 10 y Principal,

Redención Minas Camaguey

Código Postal: 74230

Cuba

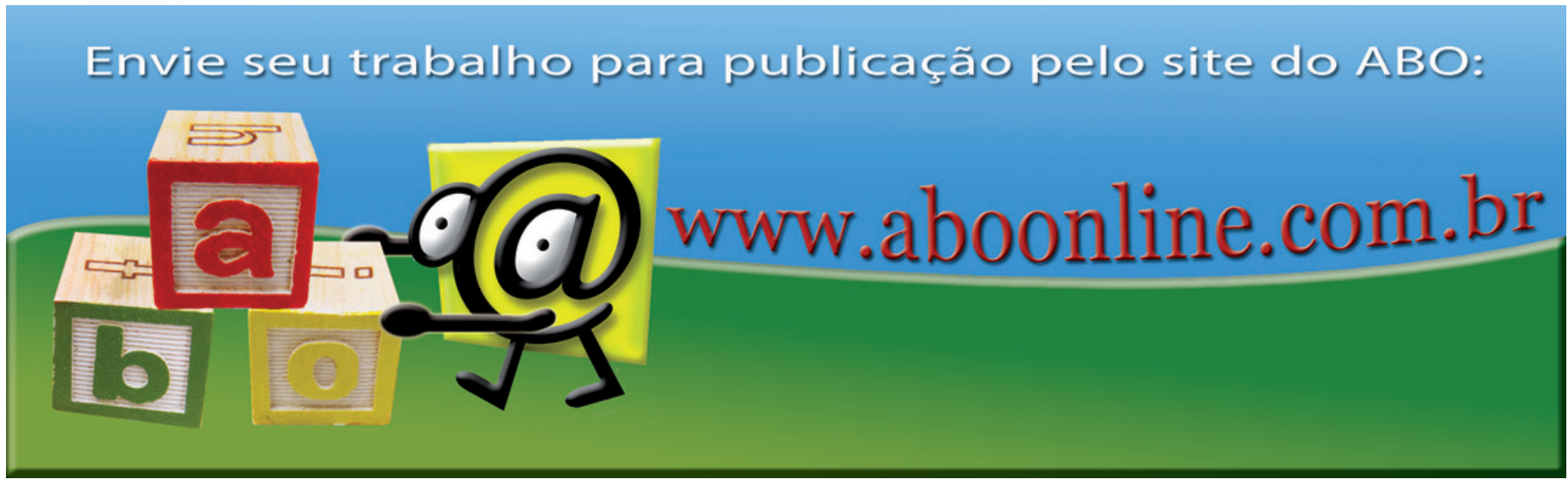

